\title{
МІЖМОВНА ІДІОМАТИЧНІСТЬ В АСПЕКТІ МІЖКУЛЬТУРНОЇ КОМУНІКАЦЇ̈ (АНГЛІЙСЬКО-УКРАЇНСЬКІ ВІДПОВІДНИКИ)
}

Клименко І. М. Міжмовна ідіоматичність в аспекті міжкультурної комунікації (англійсько-українські відповідники).

У статті міжмовні ідіоматичні відповідники досліджується як специфічні форми вираження думки в англійській та українській мовах, що зумовлюються етнокультурними та етномовними факторами. Аналізуються випадки ізоморфізму та анізоморфізму в ідіоматичних одиницях, що зіставляються.

Ключові слова: міжмовна ідіоматичність, міжмовні відповідники, ізоморфізм, анізоморфізм.

Клименко И. М. Межъязыковая идиоматичность в аспекте межкультурной коммуникации (английско-украинские соответствия).

В статье межъязыковые идиоматические соответствия исследуются как специфические формы выражения мысли в английском и украинском языках, обусловливаемые этнокультурными и этноязыковыми факторами. Анализируются случаи изоморфизма и анизоморфизма в сопоставляемых идиоматичных единиц.

Ключевые слова: межъязыковая идиоматичность, межъязыковые соответствия, изоморфизм, анизоморфизм.

Klymenko I. M. Interlingual idiomaticity and cross-cultural communication (English-Ukrainian correspondences).

The paper examines interlingual idiomatic correspondences in English and Ukrainian as specific mental forms predetermined by cultural, ethnic and linguistic factors. It studies the cases of isomorphism and anisomorphism of the contrasted idioms.

Key words: interlingual idiomaticity, interlingual correspondences, isomorphism and anisomorphism.

Адекватному розумінню іншокультурних цінностей узагалі й мовних особливостей зокрема перешкоджає відмінність знакових систем, що конститують етнокультури, і передусім - етномови. Кожна етномова характеризується як культурною, так i внутрішньою структурною специфікою. Ідея етномовної своєрідності закладена у значенні й внутрішній формі терміна «ідіоматичність». Незважаючи на значні успіхи, досягнуті у вивченні цього явища, у лінгвістиці поки що не розроблена теорія, яка трактує ідіоматичність у єдиній системі категорій. При розгляді теорії мовної ідіоматики бралися до уваги всі відповідні досягнення сучасного мовознавства $[2 ; 3 ; 4 ; 7 ; 8]$.

На сьогодні в лінгвістиці склалися дві традиції дослідження мовної ідіоматики - європейська континентальна й англоамериканська [8; 9]. У вітчизняній науці грунтовно розроблена теорія 
фразеології, проте іншим ідіоматичним мовним одиницям приділено менше уваги. При цьому обсяг поняття «ідіома» (фразеологізм або один з розрядів фразеологізмів) вужчий за обсяг поняття «ідіоматична мовна одиниця», тобто одиниця, у якої значення цілого не виводиться 3 суми значень частин. У рамках англо-американської традиції створено чимало цікавих праць, які, щоправда, не склалися в єдину лінгвістичну галузь, а витлумачення ідіоми як будь-якої форми вираження, специфічної для цієї мови, ширше за теоретичне трактування ідіоми як мовної одиниці, значення якої не виводиться 3 суми значень іï частин.

Слід розмежовувати поняття «ідіоетнізм мовлення» та «ідіоетнізм мови» [6, с. 13]. Ідіоетнізм мовлення як національна специфіка форми мови складається 3 таких параметрів, як специфічний відбір мовних одиниць, їх відносна частотність у певних типах мовних ситуацій і їх комбінування в мові. Ідіоматичність мови, що розуміється в широкому сенсі як національна специфіка іiі форми, визначається анізоморфізмом різномовних систем.

Система мови, як правило, допускає різноманітність способів вираження однієї і тієї ж думки. Але норма й реальні правила використання обмежують цю розмаїтість, надаючи перевагу одним способам над іншими. Так, фраза I want to eat (від укр. Я хочу їсти) для носія англійської мови може бути зрозумілою і в принципі допустимою, але незвичайною й нетиповою для живого спілкування (тобто ненормативною), тоді як фраза I feel hungry сприймається як природна й регулярно вживана в мові, тобто нормативна. Аналогічна відмінність спостерігається в парі висловлювань 3 галузі телефонних кліше: Говорить Петренко (калька з англійської Petrenko's speaking) і Петренко слухає.

Ідіоматичні одиниці англійської й української мов можуть мати як схожі, так і відмінні риси [3; 7]. Схожість структур називається аналогією. Крайній прояв аналогії - ізоморфізм, тобто взаємна відповідність структур мовних об'єктів (to wash one's hands - умити руки). Якщо структури об'єктів тотожні лише в загальних рисах, але різняться в деталях, вони визначаються як анізоморфні (red tape бюрократичні методи). А явище анізоморфізму полягає в менш точній, приблизній відповідності мовних об'єктів. Спільні компоненти формальних i змістовних структур називаються інтегральними ознаками, а відмінні - диференційними.

Серед підходів до вивчення міжмовної ідіоматичності 
вирізняють семасіологічний (від форми вираження до змісту) та ономасіологічний (від змісту до вираження) [9, с. 256, 334]. У першому напрямі зіставляються різномовні одиниці, ізоморфні у плані вираження, але анізоморфні у плані змісту (wind in the head «зазнайство» - вітер y голові «легковажність»), у другому зіставленню підлягають міжмовні одиниці, однакові або близькі у плані змісту, але не зовсім однакові у плані вираження (to call a spade a spade - називати речі своӥми іменами).

Відношення ізоморфізму й анізоморфізму можна визнати як корелюючі 3 лексико-семантичними на ідіоматичному рівні в англійській та українській мовах. Такі відношення зводяться до трьох основних типів: еквівалентність, семантичне включення, семантичне пересічення і безеквівалентність $[1 ; 5]$.

Еквівалентність розуміється як рівноцінність, рівнозначність одиниць, що зіставляються. Це означає повний збіг у плані семантики та структури ідіоми в англійській та українській мовах, які, як правило, походять з давніх джерел (Біблії, давніх міфів, висловів історичних діячів). Еквівалентність представлена одиницями повністю ізоморфними 3 нульовою взаємною ідіоматичністю (Achilles' heel ахіллесова п'ята).

Лексико-семантичні відношення включення означають, що в семантичній структурі фразеологізмів одної мови міститься більше лексико-семантичних варіантів значення, ніж в іншій. Відношення включення можуть також виражати відмінності у стилістичному та конотативному аспектах (on smb's hands - «resting on one as a responsibility» та на руках - 1) «під опікою»; 2) «у розпорядженні, у володінні»). Відношення пересічення наявні, коли частина лексикосемантичних варіантів значення є спільною як для англійської, так і для української мов (to be on one’s feet - 1) «be standing»; 2) «rise (to speak)»; 3) «be in good health after an illness» та бути на ногах - 1) «не спати»; 2) «клопотати, перебувати у турботах»; 3) «бути здоровим після хвороби»; 4) «стояти»). Але в кожній мові наявні і відмінні значення для стійких сполучень із спільним семантичним ядром. Відношення часткового збігу ілюструються анізоморфними взаємно ідіоматичними одиницями.

Лексико-семантичні відношення безеквівалентності, притаманні ідіомам, семантика яких співвідноситься зі специфічними для англійськомовної або української культури реаліями, що їхній змістовний план майже неможливо зіставити з будь-яким поняттям в 
іншій мові (buck eуe - «кінський каштан, що використовується як талісман»). Це випадок абсолютної міжмовної ідіоматичності, найвищого прояву анізоморфізму.

При визначенні міжмовної ідіоматичності слід брати до уваги характер представлення денотата у знакові й характер мотивування значення мовної одиниці, що випливає 3 нього. Міжмовна ідіоматичність визначається через поняття «мотиваційний сектор», «мотиваційна модель» і «структурна своєрідність» [6, с. 23-25]. Мотиваційний сектор - це частина структури мовної одиниці, що охоплює план змісту й усі мотиваційно-значущі рівні плану іiі вираження. Мотиваторами значення можуть виступати:

- образна основа (ass «безглузда людина», буквально «осел»);

- словотворча структура (screwdriver «викрутка», буквально «иурупозавертувач»);

- морфо-синтаксична структура (baker's shop «хлібна крамниця»);

- фонетична структури (rattle «гуркіт; брязкальце, тріскачка»).

Міжмовна структурно-семантична мотиваційна модель - це інваріантна частина мотиваційних секторів ряду різномовних аналогів [9, с. 186]. Структурна своєрідність є позитивною структурною відмінністю мовної одиниці від іiі аналогів в інших мовах, що виражається в опозиціях диференційних структурних ознак. Міжмовну ідіоматичнисть можна розглядати під різними кутами зору. Так, міжмовна ідіоматичність як відношення між структурами мовних одиниць - це їх анізоморфізм (відмінність) у рамках мотиваційних секторів, а як властивість мовної одиниці - це їі структурна своєрідність щодо іншомовних аналогів. На практиці в основному досліджується ідіоматичність аналогів ізоморфних в одному плані, але анізоморфних в іншому. Інакше кажучи, різниця у плані змісту не відповідає різниці у плані вираження і навпаки.

Мовна одиниця, що має ізоморфні й анізоморфні аналоги в модельному ряду, має відносну міжмовну ідіоматичність (англ. white night - безсонна ніч; укр. біла ніч - літня ніч у північних широтах). Одиниця, що не має ізоморфних аналогів у модельному ряду, має абсолютну міжмовну ідіоматичність (унікальність): three tailors from Tooley Street - cамозванці. Одиниця, що має тільки ізоморфні аналоги, не володіє міжмовною ідіоматичністю (тобото вона дорівнює нулю): to be in the seventh heaven - бути на сьомому небі. Відносність або абсолютність $є$ якісною характеристикою міжмовної ідіоматичності. 
Ступінь (кількісна характеристика) міжмовної ідіоматичності варіює від нульового до максимального й обмежується рамками структурної складності мовних одиниць [6; 7]. Він визначається співвідношенням кількості нееквівалентних диференційних структурних ознак в аналогів, що зіставляються. Ідіоматичнішим є той аналог, який структурно складніший, тому що він має такі структурні ознаки, яким не відповідають ніякі (ні тотожні, ні еквівалентні) ознаки у простішого аналога (cat's paw - знаряддя в чиїхось руках). Англійський аналог більш ідіоматичний завдяки яскравій образній мотивації. Ступінь міжмовної ідіоматичності тісно пов'язаний 3 ii симетрією / асиметрією, що визначається рівним або нерівним числом диференційних структурних ознак в аналогів, що зіставляються. Ідіоматичність в останньому прикладі асиметрична. Кількісно рівна структурна своєрідність аналогів $є$ симетричною міжмовною ідіоматичністю (idol of the market place - примари ринку).

Зіставляючи англійські та українські ідіоматичні аналоги, ми здійснювали міжмовний ідіоматологічний аналіз, метою якого було встановлення специфіки відношень планів змісту і планів вираження в порівнюваних ідіом, характеру їх ізоморфізму / анізоморфізму. При цьому встановлювався структурний інваріант ідіоми (абстрактний структурний елемент моделі в абстрагуванні від конкретних реалізацій), а на його тлі - характер опозицій диференційних ознак. Наведемо приклади:

- Англ. the fifth column й укр. n'ята колона. У них план змісту: «таємні помічники ворога» = «таємні помічники ворога», план вираження: the fifth column = n'ята колона. Це ізоморфні аналоги. Вони мають нульову взаємну ідіоматичність.

- Англ. When pigs fly й укр. Коли рак свисне. Їхній план змісту: «ніколи» = «ніколи», план вираження: When pigs fly - Коли рак свисне. Це анізоморфні, взаємно ідіоматичні аналоги.

- Англ. to lead by the nose й укр. водити за носа. План змісту: «помикати» - «дурити», план вираження: to lead by the nose = водити за носа. Це теж анізоморфні аналоги. Вони володіють взаємною ідіоматичністю.

- Ще один приклад: англ. sea dog (досвідчений моряк) й укр. гончий пес (собака певної породи). Ці різномовні одиниці не ізоморфні ні в одному 3 планів, не $\epsilon$ аналогами i, значить, не підлягають ідіоматологічному зіставленню через занадто великі розбіжності в обох планах. 
Нерозривна єдність схожості й відмінності - це те, що споріднює типологічні й ідіоматологічні дослідження. Глибина занурення у структуру аналогів визначається метою аналізу. Коли достатній приблизний погляд на речі, деякі різномовні аналоги вважаються практично ізоморфними, але при детальному підході вони можуть виявитися в тій або тій мірі взаємно ідіоматичними, наприклад, коли до аналізу залучаються фонетичні особливості одиниць.

У процесі аналізу необхідно брати до уваги також і фактори міжмовної ідіоматичності: фактор образної основи ідіоми та фактор стійкості. Образна основа фіксується засобами плану вираження i може бути експліцитною (явною): roundabout way - обхідний илях та імпліцитною (прихованою), що проявляється з усього спектру стійких сполучень 3 певним словом у певному значенні: to get the second breath - знаходити друге дихання. Стійке сполучення зі словом breath породжене прихованою метафорою «деякий запас чогось». Образна основа має культурно й історично зумовлений характер. Фактор стійкості трактується як обсяг інваріантності, властивий різним аспектам стійких сполучень, що зумовлює їх відтворюваність у готовому вигляді $[4$, с. 46]. Як показав аналіз матеріалу, чим вищий поріг стійкості вихідної одиниці порівняння, тим вищий ступінь міжмовної ідіоматичності в порівнюваних одиниць. Фактор стійкості $є$ одним із важливих аспектів порівняння англійських та українських ідіоматичних аналогів й еквівалентів, бо ступінь та пороги стійкості в різних мовах не завжди сзбігаються.

Розв'язання теоретичних i прикладних завдань, пов'язаних iз поглибленням крос-культурного взаєморозуміння й підвищенням ефективності міжетнічної комунікації, потребує глибокого осмислення поняття «своєрідність культур і мов» й опису цієї своєрідності в точних категоріях. Наше завдання полягало не в тому, щоб послідовно описати етнічну специфіку англійської або української мови, а в тому, щоб розглянути підходи до теорії міжмовної ідіоматичності й можливості застосування цієї теорії на практиці, на конкретному матеріалі, що сприятиме подальшому вивченню ідіоматики різних мов, а також дослідженням у царинах порівняльної типології, перекладознавства, міжкультурної комунікації та лінгвокраїнознавства.

\section{Література}

1. Гак В. Г. Языковые преобразования : [монография] / Владимир Григорьевич Гак. - М. : Наука, 1998. -312 с. 
2. Копыленко М. М. Очерки по общей фразеологии : фразеосочетания в системе языка : [монография] / М. М. Копыленко, З. Д. Попова. - Воронеж : Изд-во ВГУ, 1989. - 186 с.

3. Кочерган М. П. Основи зіставного мовознавства : [підручник] / Михайло Петрович Кочерган. - К. : Академія, 2006. - 424 с.

4. Кунин А. В. Курс фразеологии современного английского языка : [учебное пособие] / Александр Владимирович Кунин. - М. : Высшая школа, 1996. - 381 с.

5. Манакин В. Н. Сравнительная лексикология : [монография] / Владимир Николаевич Манакин. - К. : Знання, 2004. - 326 с.

6. Савицкий В. М. Основы общей теории идиоматики : [монография] / Владимир Михайлович Савицкий. - М. : Гнозис, 2006. - 208 с.

7. Korunets I. V. Contrastive Typology of the English and Ukrainian Languages : [manual] / IlkoV. Korunets. - K. : Lybid, 1995. - 239 p.

8. Makkai A. Idiom Structure in English : [monograph] / A. Makkai. - The Hague, 1987. -365 c.

9. Matthews P. The Concise Oxford Dictionary of Linguistics / Peter Matthews. Oxford: Oxford University Press, 1997. - 410 p. 